\title{
Microbial degradation of textile industry effluents: A review
}

\author{
Aneela Sharif*, Zahida Nasreen, Rabia Bashir and Sehrish Kalsoom \\ Department of Zoology, University of Mianwali-Pakistan \\ *Corresponding author's email: aneelasharif111@gmail.com \\ Citation \\ Aneela Sharif, Zahida Nasreen, Rabia Bashir and Sehrish Kalsoom. Microbial degradation of textile industry \\ effluents: A review. Pure and Applied Biology. Vol. 9, Issue 4, pp2361-2382. \\ http://dx.doi.org/10.19045/bspab.2020.90251
}

Received: 09/03/2020 Revised: 16/06/2020

Accepted: $24 / 06 / 2020$

Online First: 18/07/2020

\section{Abstract}

During textile processing, different waste materials are produced at different stages including dyes and wastewater. These chemicals and wastewater are ultimately released into environment that negatively affects its biota because of detrimental changes brought into the surrounding by these unused and untreated materials. The major problems being imposed by textile industry include: excessive usage of water, control of its frequent discharge into environment and treatment of this effluent loaded waste water. Industries are struggling to find out some novel solutions for treatment of these wastes to diminish the environmental damage being caused by effluent discharge. In recent years, there is an increasing trend of using different kinds of microorganisms for degradation purpose of textile industries effluents. Because of low cost and long lasting effect of biological remediation of industrial wastes, there has been an increasing demand for new and novel biological solutions for industrial effluent management. In this context, this review summarize major textile dyes, different bioremediation ways by which textile dye effluents can be treated and microbes capable of degradation and decolorization that can be applied in order to develop cost effective methods for textile effluents treatment.

Keywords: Azo dyes; Decolorization; Microbial degradation; Textile effluents

\section{Introduction}

Textile industry is considered one of the largest industry when it comes to amount of chemicals being used and thus it is the major contributor of chemical pollution in our environment. Complex chemicals and water is extensively used in textile industry during textile processing and untreated and unused leftover substances are released as waste water. This wastewater is heavily loaded with complex chemical compounds thus making this wastewater high in $\mathrm{pH}$, color and lethal compounds. The mixing of this untreated wastewater into fresh water resources like ponds, rivers, streams, canals etc. is increasing water pollution ultimately affecting the aquatic biota [1, 2]. Textile industry effluents are a mixture of many polluting substances of complex chemical nature including organochlorine-based pesticides to heavy metals and these are mostly important parts of different types of dyes being used in the dyeing process of fabrics [3].

Effective treatment of fabric industry discharge has thus become a major ecological problem. Because it is very difficult to eradicate dyes from textile waste discharge, there must be some proper treatment processes for effluents to be released into the 
environment without affecting environmental health $[4,5]$. In a broader sense, frequent encounter with textile dye effluents is a potential health threat and this has been reported to be direct or in direct cause of various health problems which include suppression of immunity system, autoimmune diseases, various complications of respiration, blood circulation, damage to central nervous system and neurobehavioral disorders, allergic reactions, different type of cancerous diseases, vomiting, copious diarrhea, tissue damage, eye skin disorders, eye infections, lung related problems are names to few [6].

Now-a-days, growing trend toward the practice of using microorganisms for environmentally friendly treatment of textile effluents has gain importance. Some microbes are reported to have potential to break down or absorb a large number of textile dyes effluents $[7,8]$.

In fact, some microorganisms which belong to different taxonomic groups such as different strains of bacteria, white rot fungi and algae also have ability to break down and decolorize various complex colored compounds that otherwise are difficult to remove from environment [9].

It is well recognized fact that under certain conditions, different bacterial strains have high capability to mineralize, decolorize and degrade different dyes [10, 11]. Different bacterial strains with potentiality to disintegrate textile dyes have drawn the attention of scientific community and there has been a growing interest toward this [12]. Bacterial oxidoreductive enzymes which include laccase, azoreductases etc. actively participate in dye decolorization activity of bacteria especially in azo dye color removal [13, 14]. Bacterial azo dye degradation involves an electron donor and sequence of enzymatic steps aided by azoreductase that catalyze the cleavage of azo linkages [15, $16]$.
Therefore, it is possible to exploit the ability of bacterial azoreductase enzymes to catalyze the azo bond cleavage in azo dye compounds for development of effective, biodegradable methods for textile effluents management [17].

Different algal sp. (Chlorella sp. Oscillatoria $s p$. etc) have also been investigated to check the efficiency of their azoreductase enzymes for disintegration of textile based azo dyes. According to some studies, the algal azo reductases have been shown to produce aromatic amines by breaking down azo bond of azo dye compounds. In relation to this, there are some algae that can carry out the direct degradation of azo dyes instead of converting them into aromatic compounds first [18].

Another eco-friendly approach toward biodegradation of textile dyes is the application of lignin degrading fungi and their enzyme complexes. Ligninolytic fungi contain an enzymatic system composed of three principal fungal enzymes: laccase, lignin peroxidase (LiP) and manganese peroxidase $(\mathrm{MnP})$ and this system of three enzymes have been found to impart degradative ability to ligninolytic fungi $[19,20]$. Textile industry waste water containing different types of dyes can be treated efficiently before its discharge by white-rot fungi that can decolorize azo dyes [21].

Lignin-degrading system (LDS) of fungi has been reported for effective degradation of variety of industrial pollutants. The effectiveness of pollutant degradation depends upon two factors:

1) Nature of contaminant

2) And the fungal $s p$. carrying out degradation processes $[22,23]$.

The different microbial enzyme systems like lignin degradation system of white rot fungi are being explored extensively to study the characteristics of these enzymes and to check their suitability for the decomposition of colored compounds [24]. 
Enzymes can be considered as biochemical mean for effective wastewater treatment. Both intracellular and extracellular microbial enzymes can be utilized for treatment purposes.

Enzymes are very efficient biological catalysts. These have the ability to target a specific pollutant without any effect on other components present in the effluent. Nor like fungi, the yeast can decolorize the dyes and can survive even in hostile conditions [25, 26].

The biosorption or uptake of chemicals by microbial mass is also useful. Biomass from different microbes such as algae, yeast, filamentous fungi and bacteria are reported to eliminate dyes through biosorption process [27].

\section{Textile industry effluents}

Dyes, pigments and aromatic compounds are among some of most commonly used chemicals which have numerous textile industry applications such as in dying, tanning of leather and also for coloring of different stuff being used in textile industries [27]. Different chemical substances discharged from the textile industries become a constant environmental pollutant. Serious environmental problems arise due to untreated effluents being released from textile industry sometimes to such levels that can seriously threaten human health, aquatic biota, domesticated animals and livestock and leave negative impacts on entire surroundings [28]. Out of 0.7 million tons dyes being produced in textile industry around the globe annually, it is assessed that about 200,000 tons of these resistant compounds are lost every year as effluent because of faulty dying processes $[29,30]$. Unluckily most of these remain in the environment because of their high consistency against physical, chemical and microbial degradation and thus are continues threat to environment or to flora and fauna [31].

\section{Textile industry dyes}

Due to coloring properties, different type of dyes and pigments are widely used in textile industry as well as in other industries such as paper, plastics, leathers, and cosmetics industry. Large amount of water is used in textile processing that is being released untreated into the environment [32]. Dye effluents are one of the main pollutants carried to the environment, mainly by textiles industries. Classification of dyes depends upon their applications and chemical nature. There are two main components of a dye, first a group of atoms that causes dye color is known as chromophores and second are electron withdrawing or donating constituents of chromophores, called auxochromes [33]. The most predominant examples of chromophores are azo $(-\mathrm{N}=\mathrm{N}-)$, carbonyl $(-\mathrm{C}=\mathrm{O})$, methine $(-\mathrm{CH}=)$, nitro $(-$ $\mathrm{NO} 2)$ and quinoid groups. The examples of main auxochromes are amine (-NH3), carboxyl $(-\mathrm{COOH})$, sulfonate $(-\mathrm{SO} 3 \mathrm{H})$ and hydroxyl $(-\mathrm{OH})$ groups. One the basis of their chemical properties, auxochromes can fit into the following dye classes ; reactive, direct, acid, basic, disperse, pigment, vat, anionic, Sulphur, solvent and disperse dyes [34]. Azo dyes dominate with the maximum diversity of colors and are usually considered as largest class of dyes owing to their coloring properties [35]. Azo, anthraquinone and phthalocyanine are three most commonly used dyes that have high toxicity and also carcinogenic properties [11]. Because these are easy to manufacture, azo dye occupy approximately $80 \%$ of yearly making of commercial dyes throughout the world. Azo dyes (Table 1), as named on the basis of one or more azo bond (R1-N=N-R2) present in them, account for approximately $60-70 \%$ of all textile dyestuffs used in current era [36]. Because of their poor absorbability to the fibers and because of their constant chemical nature, their removal is very difficult from waste water by the usual treatments [37]. 
Different types of dyes are being used in industries these days. Fabrics having nitrogen such as wool, polyamine and silk are dyed by acidic dyes which are considered as largest class of dyes [38]. Basically, there are three types of textile dyes (Table 2) that are cationic, anionic and nonionic types. Anionic dyes commonly include acid, reactive and direct dyes. Only one type of cationic dye being utilized in textile industry is basic dyes. Nonionic dyes which do not undergo ionization in solution are disperse dyes [39].

Table 1. Some azo dyes are as follow

\begin{tabular}{|c|c|c|c|}
\hline Dye & Type & Chemical nature & References \\
\hline Direct blue & Direct dye & Diazodye & {$[40]$} \\
\hline Chrysoidine & Basic dye & Monoazo, cationic & {$[\mathbf{4 0}]$} \\
\hline Procion navy blue HER & Reactive dye & Azodye & {$[\mathbf{4 0}]$} \\
\hline Suoranol Red & Acid dye & Diazo & {$[\mathbf{4 0}]$} \\
\hline Golden yellow HER & NA & Sulfonated diazo & {$[41]$} \\
\hline Reactive red HE3B & NA & Sulfonated monoazo & {$[41]$} \\
\hline Disperse brown 3RL & NA & Monoazo & {$[41]$} \\
\hline
\end{tabular}

Table 2. Characterization of different dye classes is as follow

\begin{tabular}{|c|c|c|c|c|c|c|}
\hline $\begin{array}{c}\text { Dye } \\
\text { Class }\end{array}$ & Characters & Solubility & Substrate & $\begin{array}{c}\text { Major Chemical } \\
\text { constituent }\end{array}$ & $\begin{array}{c}\text { Mechanism of } \\
\text { Rection }\end{array}$ & References \\
\hline Acid & Anionic & $\begin{array}{l}\text { Soluble in } \\
\text { water }\end{array}$ & $\begin{array}{l}\text { Nylon, } \\
\text { wool, silk, } \\
\text { modified } \\
\text { acrylic }\end{array}$ & $\begin{array}{c}\text { azo, } \\
\text { anthraquinones } \\
\text { and } \\
\text { triarylmethanes, } \\
\text { iminoacetone, } \\
\text { nitro, nitrous and } \\
\text { quinoline, }\end{array}$ & $\begin{array}{l}\text { Applied from } \\
\text { neutral to } \\
\text { acidic dye } \\
\text { baths }\end{array}$ & [42] \\
\hline Basic & Cationic, & $\begin{array}{l}\text { Soluble in } \\
\text { water }\end{array}$ & $\begin{array}{l}\text { Modified } \\
\text { nylon, } \\
\text { polyester, } \\
\text { modified } \\
\text { acrylic }\end{array}$ & $\begin{array}{c}\text { azo, } \\
\text { anthraquinone, } \\
\text { triarylmethane, } \\
\text { methane, thiazine, } \\
\text { oxazine, acridine } \\
\text { and quinoline, }\end{array}$ & $\begin{array}{l}\text { Applied from } \\
\text { acidic dye } \\
\text { baths }\end{array}$ & [42] \\
\hline Direct & Anionic & $\begin{array}{l}\text { Soluble in } \\
\text { water }\end{array}$ & $\begin{array}{l}\text { Cotton, } \\
\text { rayon, } \\
\text { leather, } \\
\text { nylon }\end{array}$ & $\begin{array}{l}\text { azo compounds, } \\
\text { with thiazoles, } \\
\text { phtalocyanines } \\
\text { and oxazines }\end{array}$ & $\begin{array}{l}\text { Applied from } \\
\text { neutral or } \\
\text { slightly } \\
\text { alkaline baths }\end{array}$ & [42] \\
\hline $\begin{array}{l}\text { Reacti } \\
\text { ve }\end{array}$ & Anionic & $\begin{array}{l}\text { Soluble in } \\
\text { water }\end{array}$ & $\begin{array}{l}\text { Cotton, } \\
\text { nylon, silk, } \\
\text { wool }\end{array}$ & $\begin{array}{c}\text { azo compounds, } \\
\text { anthraquinones } \\
\text { and } \\
\text { phtalocyanines }\end{array}$ & $\begin{array}{l}\text { Reactive site } \\
\text { on dye reacts } \\
\text { with } \\
\text { functional } \\
\text { group on fiber } \\
\text { to bind } \\
\text { dye covalently } \\
\text { under } \\
\text { influence of } \\
\text { heat and } \\
\text { pH(alkaline) }\end{array}$ & [42] \\
\hline
\end{tabular}




\begin{tabular}{|c|c|c|c|c|c|c|}
\hline & & & & $\begin{array}{c}\text { Fine aqueous } \\
\text { dispersions } \\
\text { often } \\
\text { applied by } \\
\text { high }\end{array}$ & \\
Disper \\
se
\end{tabular}

One of the most extensively applied dyes colorants in fabric industry are azo dyes making up to $60 \pm 70 \%$ of all dyestuff, anthraquinone group being on second in this list. Biological management of azo dyes from effluents is highly effective and these dyes are soluble in solution. Highly degradation resistant dyes are the type of dyes known as reactive dyes that are present in effluents released from textile industry [7]. Now-adays, practice of using green technologies mainly for the purpose of protecting environment and for reducing environmental pollution is gaining wide attention. Microbes are widely being used for treatment of industrial effluents which have certain advantages. Some microbes being used for degradation are described below:

\section{Role of Bacteria in biodegradation}

Several researchers have studied different bacterial species for bioremediation of dyes, metals, soils and waters that are contaminated by textile effluents. Dyes that contain carcinogenic compounds, heavy metals, halogen containing compounds, bleaching agents containing chlorine, formaldehyde etc. are some of the main pollutants of textile wastewater $[43,44]$. Bacteria able to decolorize dye (Table 3 ) in pure cultures have already been described [45]. The mixed microbial culture bears more benefits then the application of pure cultures in the disintegration of colorants being utilized in textile industry. Dyes molecules may be directly attacked by different bacterial species or some strains are even able to further degrade the break down products that are formed by another strain [46].

The aerobic degradation of azo dye by bacteria is not effective; however, a group of aerobic and anaerobic bacteria has been shown to degrade some azo dyes (Table 4). Pseudomonas leuteola and Bacillus subtilis are some of the bacteria being used for anaerobic degradation [51].

Table 3. Percentage efficiency of some bacterial species to decolorize azo dyes is given in the following table

\begin{tabular}{|c|c|c|c|}
\hline Bacterial Specie & \% Efficiency Of decolorization & Optimum PH Required & References \\
\hline Pseudomonas putida & $90 \%$ & 7 & {$[8]$} \\
\hline Bacillus cereus, & $65 \%$ & $7-9$ & {$[8]$} \\
\hline Bacillus subtilis & $54 \%$ & 7 & {$[8]$} \\
\hline Pseudomonas $s p$ & $78 \%$ & 7 & {$[47]$} \\
\hline Bacillus mycoides & $76 \%$ & N/A & {$[47]$} \\
\hline Micrococcus sp. & $77 \%$ & N/A & {$[47]$} \\
\hline Chryseomonas luteola & $42 \%$ & N/A & {$[48]$} \\
\hline Pseudomonas & $42.5 \%$ & N/A & {$[48]$} \\
\hline
\end{tabular}




\begin{tabular}{|c|c|c|c|}
\hline aeruginosa & & & \\
\hline Aeromonas hydrophila & $90 \%$ & 7 & {$[8]$} \\
\hline Pseudomonas sp. & $97 \%$ & N/A & {$[41]$} \\
\hline Staphylococcus aureus & $79 \%$ & N/A & {$[49]$} \\
\hline Bacillus sp & $83 \%$ & N/A & {$[49]$} \\
\hline Klebsiella ozaenae & $95.89 \%$ & 7 & {$[50]$} \\
\hline
\end{tabular}

Table 4. Some of bacterial strains degrading synthetic dyes are listed in the following table

\begin{tabular}{|c|c|c|}
\hline Bacterial strain & Synthetic dye & References \\
\hline Bacillus subtilis & Reactive azo dyes & {$[\mathbf{5 1}]$} \\
\hline Aeromonas hydrophila & Acid Orange 7, Reactive Blue 160, & {$[\mathbf{5 2}]$} \\
\hline Escherichia coli & Ethyl Red, Methyl Red & {$[\mathbf{5 3}]$} \\
\hline Sphingomonas xenophaga & Acid Orange 7, 10 & {$[\mathbf{5 4}]$} \\
\hline Rhizobium radiobacter & Reactive Red 141 & {$[\mathbf{5 4}]$} \\
\hline Pseudomonas luteola & Reactive azo dyes & {$[\mathbf{5 5}]$} \\
\hline Corynebacterium Glutamicum & Reactive Yellow 2 & {$[\mathbf{5 6}]$} \\
\hline Pseudomonas aeruginos & Direct Orange 39 & {$[\mathbf{5 7}]$} \\
\hline Staphylococcus arlettae & Reactive Yellow 107, Reactive Red 198 and Direct & {$[57]$} \\
\hline Alcaligenes faecalis & Blue 71 & {$[\mathbf{5 8}]$} \\
\hline Enterobacter agglomerans & Reactive, azo dyes, disperse dyes and & phthalocyanine dyes \\
\hline Bacillus megaterium & Methyl Red & {$[\mathbf{5 9}]$} \\
\hline
\end{tabular}

Microbial mechanism to degrade and decolorize azo dye

Biological management of textile industry dyes is an efficient and environmentally friendly process. The Microbial mechanism for degradation and decolorization of most problematic textile dyes that are azo dyes involves cleavage of azo bonds in azo compounds, thus causing color removal of azo compounds. Azo dyes first undergo reductive cleavage and then resulting breakdown products which are aromatic amines mainly are metabolized in the presence of oxygen. Mostly, dyes are mineralized into simple inorganic compounds that are harmless for living organism and do not threat their life [61].

Microbial electron transport chain contains reduced flavin nucleotides for which azo dye in an oxidizing agent and is itself reduced during oxidation of flavin nucleotides and this process is followed by the reduced flavin nucleotides undergoing reoxidation. This process usually requires an additional carbon source for decolorization and degradation to proceed at a feasible speed [62]. Some aerobic microbes utilize azo dyes as their only source of carbon and nitrogen, in others strains reduction of azo group can only be catalyzed by oxygen-tolerant azo reductases. This carbon is changed to methane and carbon dioxide, causing release of electrons. These electrons then move down electron transport chain to azo dye, which is acting as electron acceptor. Then there is reaction between electrons and azo dye, leading to reduction of azo bonds, and thus decolorization occurs [63]. Several other microbes such as bacterial strains, fungi, actinomycetes and algae are extensively been investigated for their azo dye decolorization capability $[63,64]$.

Algal degradation and decolorization of textile dyes (Phycoremediation)

Phycoremediation may be defined as the use of macro algae or microalgae for the elimination or biodegradation of pollutants, including textile dyes and xenobiotics from wastewater with simultaneous biomass 
propagation. There are large number of processes for treating polluted water, industrial effluents, dyes, different colorants, bleaching and tanning agents using microalgae aerobically as well as an anaerobically [65]. Although bacteria have pivotal importance in degradation of environmental pollutants, microalgae have been shown to have organic pollutants degradation ability (Table 5) besides providing oxygen for aerobic bacteria that can only degrade pollutants in the presence of oxygen. Indeed, there have been lots of studies proving that current environmental problems such as textile industry effluents treatments issues can be resolved by using microalgae for degradation of pollutants into eco-friendly compounds [66]. Mutagenic and carcinogenic azo dyes and their intermediates compounds are causing many health related issues and are responsible for mutagenic activities in surface water that are polluted largely by textile waste water. Their release into surface water also leads to major issues, causing obstruction of light being unable to penetrate and also hinders oxygen access into water bodies $[67,68]$. The algae are photoautotrophs and they require no carbon source. The utilization of algae for waste water treatment is an efficient and cheap cost process. The growth of photosynthetic algae is visible even in the textile industry effluents and therefore they are the possible candidate for waste water treatment [69].

Good color removal can be achieved by algal azo reductase enzymes that is capable of breaking down azo dyes. Chlorella and Oscillatoria species have been shown to produce aromatic amines through degradation of azo dyes ultimately leading to formation of simple organic compounds through further break down of these aromatic amines. Few other algal species were even able to utilize azo compounds (Table 6) as only carbon and nitrogen source. Chlorella sp. and Oscillatoria sp. have been shown to degrade and decolorize more than 30 azo dyes into less complex aromatic amines [80].

Table 5. Some of dyes and color agents removed by algae are as follow

\begin{tabular}{|c|c|c|c|}
\hline Algae & Dye removed & \% efficiency of removal & References \\
\hline Cosmarium $s p$. & Malachite Green & $92.4 \%$ & {$[70]$} \\
\hline Green Algae & Mono-azo and diazo Dyes & $68 \%$ & {$[71]$} \\
\hline Algal biomass & Malachite Green & $85 \%$ & {$[72]$} \\
\hline Green Algae & Indigo & 89.3 & {$[73]$} \\
\hline Green Algae & Direct Blue & $79 \%$ & {$[73]$} \\
\hline Green Algae & Remazol brilliant Orange & $75.3 \%$ & {$[73]$} \\
\hline Green Algae & Crystal violet & $72.5 \%$ & {$[73]$} \\
\hline Kluyveromyces maraxianus & Remazol Black-B & $98 \%$ & {$[74]$} \\
\hline Chlorella $s p$. & Indigo & $89.3 \%$ & {$[75]$} \\
\hline Chlorella $s p$. & Direct blue & $79 \%$ & {$[75]$} \\
\hline Chlorella $s p$. & Remazol brilliant orange & $75.3 \%$ & {$[75]$} \\
\hline Chlorella $s p$. & Crystal violet & $72.5 \%$ & {$[75]$} \\
\hline Spirogyra $s p$. & Blue dye & $78.29 \%$ & {$[76]$} \\
\hline Spirogyra $s p$. & Red dye & $64.21 \%$ & {$[76]$} \\
\hline Oscillatoria $s p$. & Blue dye & $76.48 \%$ & {$[76]$} \\
\hline Oscillatoria $s p$. & Red dye & $62.63 \%$ & {$[76]$} \\
\hline Phormidium & Indigo dye & $91 \%$ & {$[77]$} \\
\hline Synechococcus $s p$. & Remazol Brilliant Blue R) & $11.53 \%$ & {$[77]$} \\
\hline Lyngbya sp. & Textile dye & $73 \%$ & {$[78]$} \\
\hline Lyngbya lagerlerimi & Methyl Red & $35.61 \%$ & {$[79]$} \\
\hline
\end{tabular}




\begin{tabular}{|c|c|c|c|}
\hline Nostoc linckia & Methyl Red & $81.97 \%$ & {$[79]$} \\
\hline Oscillatoria rubescens & Basic Cationic & $85.80 \%$ & {$[79]$} \\
\hline Chlorella vulgaris & Basic Fuchsin & $91.20 \%$ & {$[79]$} \\
\hline Elkatohrix viridis & G-red & $90.75 \%$ & {$[79]$} \\
\hline
\end{tabular}

Table 6. Some of other algal species actively involved in degradation process are following

\begin{tabular}{|c|c|}
\hline Algal sp. & References \\
\hline Chlorococcum $s p$. & {$[\mathbf{8 1}]$} \\
\hline Chroococcus $s p$. & {$[81]$} \\
\hline Desmococcus $s p$. & {$[81]$} \\
\hline Chlamydomonas $s p$. & {$[81]$} \\
\hline Chlorella $s p$. & {$[82]$} \\
\hline Synechocystis $s p$. & {$[82]$} \\
\hline Phormidium $s p$. & {$[\mathbf{8 2}]$} \\
\hline Spirogyra rhizopus & {$[83]$} \\
\hline
\end{tabular}

Role of fungi in degradation and decolorization of textile dyes (Mycoremediation)

The practical of usage of fungi for achieving bioremediation of polluted soils and textile effluents is termed as mycoremediation. Different problematic substances such as petroleum hydrocarbon compounds, polychlorinated biphenyls, heavy metals (by biosorption), phenolic derived compounds, degradation resistant pesticides etc. have been reported to be degraded through mycoremediation. These hazardous compounds are used by fungi as the nutrient source in this process of mycoremediation and changed them into simpler forms also causing their decolorization (Table 7). Fungi can be classified on the bases of its degradation efficacy under following terms:

- Ligninolytic fungal degradation

- Fungal biosorption

- Mycorrhizal fungal degradation [84].

Bjerkandera adusta, Trametes versicolor, Phanerochaete chrysosporium have been approved for textile dyes treatment through their ligninolytic activities [85].

Table 7. Dyes decolorization efficiency (\%) of different fungal species is listed as follow

\begin{tabular}{|c|c|c|c|}
\hline Fungal spp. & Dye decolorized & Rates of Decolorization & References \\
\hline Aspergillus flavus SA2 & Acid Red 151(di-azo) & $97.70 \%$ & {$[\mathbf{8 6}]$} \\
\hline Alternaria spp. SA4 & Acid Red 151(di-azo) & $98.47 \%$ & {$[\mathbf{8 6}]$} \\
\hline Aspergillus tereus SA3 & Acid Red 151(di-azo) & $55 \%$ & {$[\mathbf{8 6}]$} \\
\hline Penicillium spp. SA5 & Acid Red 151(di-azo) & $65 \%$ & {$[\mathbf{8 6}]$} \\
\hline Aspergillus flavus SA2 & Orange II (mono-azo) & $48 \%$ & {$[\mathbf{8 6}]$} \\
\hline Aspergillus tereus SA3 & Orange II (mono-azo) & $44.67 \%$ & {$[\mathbf{8 6}]$} \\
\hline Alternaria spp. SA4 & Orange II (mono-azo) & $58.66 \%$ & {$[\mathbf{8 7}]$} \\
\hline Penicillium spp. SA5 & Orange II (mono-azo) & $55.68 \%$ & {$[\mathbf{8 7}]$} \\
\hline Pleurotus florida & malachite green & $90 \%$ & {$[\mathbf{8 7}]$} \\
\hline Schizophyllum commune IBL-06 & Brilliant red 80 & $84.8 \%$ & {$[\mathbf{8 7}]$} \\
\hline
\end{tabular}

\section{Role of White-Rot Fungi (WRF) In Textile Effluents Treatment}

WRF have been shown to possess extraordinary dye decolorizing ability (Table
8). These are proficient in mineralizing a wide-ranging pollutants, while bacteria are substrate specific. The main reason behind this degradative efficiency of white rot fungi 
to break down substances such pollutants and aromatic compounds is their lignin degrading enzymes, such as lignin peroxidase (LiP), manganese peroxidase $(\mathrm{MnP})$ and laccase that are not substrate-specific $[\mathbf{8 8}, 89]$. Lignin peroxidase released by Phanerochaete Chrysosporium has been reported to efficiently break down azo dye into simpler compounds [90].

Lignin, a polymer present in woody plants is broken down by WRF. The wood-rotting Phanerochaete chrysosporium is a white-rot fungus that is capable to degrade variety of xenobiotic pollutants such as dioxins, polychlorinated biphenyls (PCBs) and other chloro-organics. Coriolus versicolo, Trametes versicolor, Pleurotus ostreatus and Coriolopsis polysona are some other reported WRF that show ability to remove color from dyes [101]. LiP and Mn-dependent peroxidase $(\mathrm{MnP})$ or laccase enzymes are main agents of color removal by WRF [102, 103].

Different fungal species are also capable of reducing heavy metals from waste laden water some of which are listed in (Table 9).

Trametes versicolor is an specie of interest because of its ability to decolorize different colored compounds released from textile and other industries $[109,110]$.

Table 8. Some of synthetic textile dyes decolorizing white rot fungi are following

\begin{tabular}{|c|c|c|}
\hline WRF Strain & Dyes decolorized & References \\
\hline Bjerkandera adusta & Reactive Orange96, Reactive Violet 5 & {$[91]$} \\
\hline Lentinus tigrinus & Orange II , Reactive Blue 38 & {$[92]$} \\
\hline Phlebia brevispora & Brilliant Green, Crystal Violet & {$[93]$} \\
\hline Piptoporus betulinus & Acid Green 27, Acid Red & {$[94]$} \\
\hline Stereum rugosum & 106, Brilliant Yellow, Chrysophenine & {$[95]$} \\
\hline Funalia trogii & Remazol Brilliant Blue, Poly R-478 & {$[96]$} \\
\hline Pleurotus pulmonarius & Remazol Brillant Blue & {$[97]$} \\
\hline Pleurotus ostreatus & Amido Black & {$[98]$} \\
\hline Phanerochaete chrysosporium & Phenol Red, Bromophenol Red & {$[99]$} \\
\hline Coriolus versicolor KR-11W & Amido black 10B & {$[100]$} \\
\hline Phanerochaete chrysosporium & Congo Red, Methylene blue & {$[100]$} \\
\hline Coriolus versicolor KR-65W & Methylene blue, Poly R-478, Congo Red & {$[100]$} \\
\hline
\end{tabular}

Table 9. Some of other fungal species capable of removing heavy metals from textile waste water are listed in the given table

\begin{tabular}{|c|c|c|c|}
\hline Fungal specie & Metals & Adsorption capacity (mg g_1) & References \\
\hline Aspergillus niger & $\mathrm{Cu}$ & 5 & {$[104]$} \\
\hline Mucor rouxe & $\mathrm{Pb}$ & 17 & {$[105]$} \\
\hline Mucor rouxe & $\mathrm{Zn}$ & 4.89 & {$[105]$} \\
\hline Mucor rouxe & $\mathrm{Cd}$ & 6.94 & {$[105]$} \\
\hline Mucor rouxe & $\mathrm{Ni}$ & 5.24 & {$[105]$} \\
\hline Rhizopus nigricans & $\mathrm{Cr}$ & 47 & {$[106]$} \\
\hline Rhizopus nigricans & $\mathrm{Pb}$ & 21.3 & {$[106]$} \\
\hline $\begin{array}{c}\text { Streptoverticillium } \\
\text { cinnamoneum }\end{array}$ & $\mathrm{Zn}$ & 116 & {$[107]$} \\
\hline Penicillium chrysogenum & $\mathrm{Pb}$ & & {$[108]$} \\
\hline
\end{tabular}




\section{Fungal enzymes and biodegradation}

Fungi are the good producer when it comes to enzyme production. Surface culture method is used to produce commercial fungal enzymes [111]. White rot fungi are very successful entities with extraordinary lignin degradation ability. Extracellular oxidoreductases enzymes such as laccases, peroxidases and oxidases are produced by WRF that perform biodegradation [112]. The main role of these enzymes is to degrade lignin but because these enzymes are not substrate-specific these are also capable to break different aromatic persistent compounds (Table 10) involved in causing environment related issues [113]. WRF are better dye-decolorizers as compared to prokaryotes. P. chrysosporium is a principle decolorizer compared to other microbes, whose decolorizing capability is due to lignin peroxidase (LiP) and manganese peroxidases $(\mathrm{MnP})[114]$.

Table 10. Some of enzymes from different fungi degrading effluents are enlisted bellow

\begin{tabular}{|c|c|c|c|}
\hline Effluent & Fungal sp. & Enzyme & References \\
\hline Azo dyes & Pycnoporus sanguineis & Laccase & {$[115]$} \\
\hline Bleach plant effluents & P.sanguineis & Laccase & {$[116]$} \\
\hline PCBs & $\begin{array}{c}\text { P.chrysosporium, } \\
\text { Trametes versicolor }\end{array}$ & lignin peroxidase (Lip), Mnp & {$[117]$} \\
\hline $\begin{array}{c}\text { non phenolic aromatic } \\
\text { compounds }\end{array}$ & Penicillium chrysogenum & LiP & {$[118]$} \\
\hline phenolic compounds & P.chrysosporium & manganese peroxidase (MnP) & {$[119]$} \\
\hline $\begin{array}{c}\text { 2, 6-dimethoxyphenol } \\
\text { (DMP) }\end{array}$ & Bjerkandera adusta & $\mathrm{MnP}$ & {$[119]$} \\
\hline $\begin{array}{c}\text { Bromophenol Red, } \\
\text { Bromocresol Purple }\end{array}$ & Pleurotus ostreatus & $\mathrm{MnP}, \mathrm{MiP}$ & {$[120]$} \\
\hline Solar golden yellow R & Scyzophyllum commune & $\mathrm{MnP}$, Laccase & {$[87]$} \\
\hline
\end{tabular}

The survival of fungi depends upon their ability to adjust their metabolism according to changing level of carbon and nitrogen. Intracellular and extracellular enzymes are produced by fungi to achieve this metabolic activity and these further carry out nonspecific degradation of different resistant effluents such as aromatic hydrocarbons, organic waste, dye compounds etc. Nonsubstrate specific nature of fungal enzyme systems is the main reason behind their ability to disintegrate colored and metallic effluents [121]. Similar enzymes because of their low specificity for substrate (lignin) have also been employed successfully in the degradation of dyes. Only a few reports have shown the capability of Brown-rot fungi to remove various dyes [80].
Enzymatic degradation of textile effluents Enzymes have several beneficial characteristics related to degradation. When it comes to the amount and composition of effluents, the most polluting effluent released from industrial sector is textile wastewater $[122,123]$. The disadvantages that we face while using microorganisms for degradation activities can be overcome easily by using enzymes as an alternate [124]. Enzymes have the capability to efficiently break down a target pollutant (Table 11) with no effect on the other constituents in the wastewater. Therefore, pollutants that are quite resistant toward disintegration can easily be degraded by enzymes. Hydrolases, dehalogenases, transferases and oxidoreductases are some of the most important enzyme classes actively involved in bioremediation processes. An example of enzyme active in removal of 
pollutants is Laccase [125]. Extracellular enzymes of ligninolytic fungi, white rot fungi are important for disintegration of dyestuff and also lignin [126]. It is advantageous to use WRF for degradative purposes then bacteria. The non-substrate specific nature of extracellular enzymes such as LiP, MnP, laccase and Mn-independent versatile peroxidases (VP) give white rot fungi this extraordinary efficiency to break down resistant aromatic color compounds [127].

Microbial enzymes have many desirable properties such as they give maximum possible yields, their genetic makeup can easily be manipulated, easy availability due to absence of seasonal fluctuations and high growth of microbes than enzymes produced by plants and animals. Microbial enzymes are also important in that they have high stability and are easy to produce. Several dyes have been reported to be decolorize by white rot fungi which shows that these entities are an important alternative for management of industrial dye containing effluents [128].

Table 11. Some of the dyes being decolorized by enzyme mediated processes are as follow

\begin{tabular}{|c|c|c|}
\hline Substrate & Enzyme and their source & References \\
\hline $\begin{array}{c}\text { 3-(4 dimethyl amino-1 phenylazo) Benzene } \\
\text { sulfonic } \\
\text { acid. }\end{array}$ & Laccase from Trametes villosa & [129] \\
\hline Acid Orange 6, $7 \&$ Methyl Red & $\begin{array}{l}\text { Bacterial Oxidoreductases from sludge } \\
\text { Methanogens }\end{array}$ & {$[130]$} \\
\hline Tartrazine and Ponceau & Azo reductase from Green Algae & [130] \\
\hline Reactive Yellow & $\begin{array}{c}\text { Azo reductase from Staphylococcus } \\
\text { arlettae }\end{array}$ & [131] \\
\hline $\begin{array}{c}\text { Reactive Blue } 38 \text {, Reactive Black 5, Reactive } \\
\text { Orange } 96\end{array}$ & $\begin{array}{l}\text { Manganese peroxidase from } \\
\text { Phanerocheate chrysosporium }\end{array}$ & [132] \\
\hline reactive blue 19 & $\begin{array}{c}\text { Lacasse from Tramates } \\
\text { Versicolor }\end{array}$ & [132] \\
\hline Reactive Blue 59 & $\begin{array}{c}\text { Lignin Peroxidase from Streptomyces } \\
\text { krainskii }\end{array}$ & [133] \\
\hline $\begin{array}{c}\text { Remazol Brilliant } \\
\text { Blue R } \\
\end{array}$ & $\begin{array}{c}\text { Peroxidase and Laccase from } \\
\text { Pleurotus ostreatus }\end{array}$ & {$[134]$} \\
\hline Azo dye & $\begin{array}{c}\text { Lignin peroxidase from Penicillium } \\
\text { ochrochloron }\end{array}$ & [135] \\
\hline Azo dye & $\begin{array}{l}\text { Lignin peroxidase, tyrosinase, } \\
\text { azoreductase and riboflavin } \\
\text { reductase from Bacillus } s p \text {. }\end{array}$ & [135] \\
\hline
\end{tabular}

It was reported in another study that WRF breaks down Crystal Violet dye via $N$ demethylation The main reaction of azo dyes disintegration by bacteria includes breakage of azo bonds by an azoreductase enzyme and an electron donor. Azo dyes containing textile waste water can be bio-treated effectively by developing treatment processes that uses azoreductase producing microbes. These azoreductase enzymes can catalyze the cleavage of azo compounds by reduction [136].

The most important bacterial enzymes involved in degradation activities are azoreductases (Table 12). Azoreductases cause breakage of azo bonds $(-\mathrm{N}=\mathrm{N}-)$, producing aromatic amines which are further converted into $\mathrm{CO} 2$ and $\mathrm{H} 2 \mathrm{O}$ under aerobic environments [137]. 


\section{Yeast degradation ability}

The large absorption of dyes, heavy metals, colorants makes the yeast a good microbe for bioremediation of azo dyes (Table 13). The enzymatic degradation and adsorption or the combination of both are the main practices by which yeast degrades azo dyes. The Remazol Blue and Reactive Red dyes can be efficiently removed up to $94 \%$ and $44 \%$ respectively by using Candida tropicalis [144]. There are only quite few studies about yeast decolorization ability. Pseudozyma rugulosa and Candida krusei are the yeast strains that exhibited excellent color removal of reactive azo dyes. Saccharomyces cerevisiae effectively decolorize methyl red at different $\mathrm{pH}$ with involvement of azoreductase [145].

There is growing interest for biological treatment of waste water compounds such as textile effluents mainly dyes, metals, inorganic nutrient, and organic compounds through biosorption, biodegradation, bioaccumulation, and enzymatic mineralization [151]. The fungi reduce azo dyes by producing extracellular enzymes such as peroxidases and phenol oxidases [152].

Table 12. Bacteria with azoreductase activity are described below

\begin{tabular}{|c|c|c|}
\hline Sr. No. & Bacterial strain & References \\
\hline 1 & Pseudomonas luteola & {$[138]$} \\
\hline & Pseudomonas aeruginosa & {$[138]$} \\
\hline 3 & Klebsiella pnumoniae & {$[139]$} \\
\hline 4 & Clostridium perfringens & {$[139]$} \\
\hline 6 & Enterococcus spp & {$[140]$} \\
\hline 7 & Streptococcus $\mathrm{spp}$ & {$[\mathbf{1 4 1}]$} \\
\hline 8 & Bacillus cereus & {$[\mathbf{1 4 2}]$} \\
\hline 9 & Streptomyces $\mathrm{spp}$ & {$[\mathbf{1 4 3}]$} \\
\hline
\end{tabular}

Table 13. Some of yeast (Ascomycetes) involved in remediation of different dyes are listed here

\begin{tabular}{|c|c|c|}
\hline Yeast Sp. & Dyes & References \\
\hline Candida krusei & Reactive azo dye & {$[145]$} \\
\hline Saccharomyces cerevisiae & Malachite Green & {$[145]$} \\
\hline Candida zeylanoides & Azo benzenesulfonates & {$[146]$} \\
\hline Candida tropicalis & Reactive Blue 19, & {$[147]$} \\
\hline Candida kursei & Basic Violet 3 & {$[148]$} \\
\hline Kluyveromyces marxianus & Remazol Back B & {$[148]$} \\
\hline Pseudozyma Rugulosa & Reactive azo dye & {$[149]$} \\
\hline Torulopsis candida & Reactive Brilliant Red & {$[150]$} \\
\hline Trichosporon beigelli & Crystal Violet, Methyl violet Malachite Green & {$[150]$} \\
\hline
\end{tabular}

\section{Degradation of textile effluent through biosorption}

The absorption or uptake of chemicals by microbial mass is known as biosorption or more precisely it can also be described as " the capability of microbes to amass heavy metals from wastewater through metabolic or physiochemical paths of absorption" [153]. It mainly occurs through cell wall, whereas adsorption and absorption depending upon biomass type [154].

Algae, yeast, filamentous fungi and bacteria can be used to eliminate dyes from wastewater by biosorption by using their biomass. Heteropolysaccharide and lipid are integral part of the cell wall and have different functional groups such as amino, carboxyl, hydroxyl group and other charged components and have 
biosorption properties. Strong attractive forces develop between the azo dye and these functional groups of cell wall of different microbes such as yeast, algae bacteria and filamentous fungi. Thus these components of cell wall are responsible for biosorption capacity of microbes [155].

Biosorption is attribute of specific type of microbial biomass to make bond with and to accumulate wastes and heavy metals present in effluents. Biomass has ability to act just like a chemical element or ion exchanger that is originated from biological source. The main component of fungi, bacteria and algae responsible for biosorption is cell wall. Until now, it has been widely reported that biosorption is a perfect substitute for cleansing of metal holding effluents [156].

Biosorption with microorganisms, especially fungus (Table 9) for elimination of colorants from textile waste water has gained significant attention. Decoloring of synthetic dyes and dye effluents have been studied by using different fungi. With respect to bacterial biosorption capacity, Aeromonas sp., Pseudomonas luteola, E. coli, Bacillus subtilis and Staphylococcus aureus are some of bacterial strains being used for their bio sorbent properties for decontamination of class of dyes known as reactive dyes. The chief advantages offered by biosorption over old treatment processes include high effectiveness, low cost, minimization of sludge, recovery of metals, bio-sorbent regeneration, easiness to recover metals etc. [157].

\section{Mechanisms of biosorption}

There are many ways by which microbes can take up metals and this is due to their complex structure. There are many criteria to classify biosorption processes. Biosorption processes based on cellular metabolism can be classified as follow:

1. Metabolism dependent biosorption

2. Non -metabolism dependent biosorption

Biosorption can also be classified as intracellular/extracellular biosorption and cell surface sorption depending upon the location where metal biosorbed from effluents is found [158].

A typical biosorption route has two phases;

1. A solid phase (sorbent or biosorbent; commonly a living material)

2. And a liquid phase (solvent, usually $\mathrm{H} 2 \mathrm{O}$ ) comprising a dissolved substance to be sorbed (sorbate, a metal ion) [153].

\section{Biosorption and heavy metal removal}

Biosorption refers to the elimination of heavy metals and other harmful substances from a liquid solution by passively binding to nonliving biomass. From this, it can be concluded that process is not metabolism dependent. Bioaccumulation, in contrast refer to an active removal of various metals by living organisms and this process is controlled metabolically. Different bio-sorbents organisms include algae, bacterial strains, different yeasts strains, fungi (Table 14) can be used to treat heavy metal effluents [159, 160].

There are two chief mechanisms by which metals are biosorbed [161, 162].

1. Active biosorption (metabolism-dependent)

2. And passive (metabolism- independent).

Active process of biosorption requires specific kind of conditions such as $\mathrm{pH}$, temperature, nutrients that are necessary for maintain cellular functions. Passive biosorption processes, in contrast, occurs in living as well as in dead cells and take place under wideranging environmental conditions. The passive processes are more efficient as compared to active biosorption $[162,163]$.

Table 14. Some microbial species used in metal biosorption are follow

\begin{tabular}{|c|c|c|}
\hline Microbial spp. & Metal absorbed & References \\
\hline Saccharomyces cerevisiae, & $\mathrm{Cd}$ & {$[164]$} \\
\hline Kluyveromyces fragilis & $\mathrm{Cd}$ & {$[164]$} \\
\hline Arthrobacter sp. & $\mathrm{Pb}$ & {$[165]$} \\
\hline Penicillum chrysogenum & $\mathrm{Pb}$ & {$[165]$} \\
\hline p.digitatum & $\mathrm{Pb}$ & {$[166]$} \\
\hline
\end{tabular}




\section{Conclusion}

Microorganisms are organisms of interest because of their efficiency for degradation. These include bacteria that are useful especially for degradation of resistant azo dyes which are being used extensively in textile industry. Algae are also being used widely for degradation and decolorization of textile effluents. Several algal species have capability of degrading different dyes, colorants and also organic pollutants. Similarly, fungi also have huge importance in bioremediation process. Different fungal enzymes have potential to breakdown different dyes with greater efficiency. Most important fungal species in context of degradation is white rot fungi which can degrade complex effluents by using different enzymes. Enzymes can provide an alternate for effluent treatment because of their absorption and degradation properties. Enzymes, the biological catalysts can take up different dyes including most resistant azo dyes. The enormous absorption of dyes and heavy metals makes the yeast a good candidate for biodegradation of azo dyes. Thus it can be concluded that microorganisms have huge potential for remediation of effluents and can successfully be employed for making our environment clean and healthy. So, there is a need for further exploration of degradation capabilities of different microbes.

\section{Authors' contributions}

Analyzed the data: A Sharif \& Z Nasreen, Contributed materials/ analysis/ tools: $\mathrm{R}$ Parveen \& S Kalsoom, Wrote the paper: A Sharif.

\section{References}

1. Gao BY, Yue QY, Wang Y \& Zhou WZ (2007). Color removal from dyecontaining wastewater by magnesium chloride. J Environ Manage 82: 167-172.

2. Verma AK, Dash RR \& Bhunia R (2012). A review on chemical coagulation/flocculation technologies for removal of colo $r$ from textile wastewaters. J Environ Management 93: 154-168.
3. Conneely A, Smyth WF \& McMullan G (1999). Metabolism of the phthalocyanine textile dye remazol turquoise blue by Phanerochaete chrysosporium. FEMS Microbiol Lett 179: 333-337.

4. Lin SH \& Lin CH (1993). Treatment of textile wastewater by ozonation and chemical coagulation. Water Res 27: 1743-1748.

5. Palamthodi S, Patil D \& Patil Y (2011). Microbial degradation of textile industrial effluents. Afr J Biotechnol 10: 12657-12661.

6. Foo KY \& Hameed BH (2010). Decontamination of textile wastewater via $\mathrm{TiO} 2 /$ activated carbon composite materials. Adv Colloid Interface Sci 159: 130-143.

7. Robinson T, McMullan G, Marchant R \& Nigam P (2001). Remediation of Dyes in Textile Effluent: A Critical Review on Current Treatment Technologies with A Proposed Alternative. Bioresour Technol 77: 247-255.

8. Tripathi A \& Srivastava SK (2011). Ecofriendly Treatment of Azo Dyes: Bio decolorization using Bacterial Strains. Int J Biosci Biochem Bioinform 1:37-40.

9. Anjaneyulu Y, Chary NS \& Suman Raj DS (2005). Decolorization Of Industrial Effluents - Available Methods And Emerging Technologies - A Review. Rev Environ Sci Biotechnol 4:245-273.

10. Kapdan IK, Tekol M \& Sengul F (2003). Decolorization of Simulated Textile Wastewater in an Anaerobic-Aerobic Sequential Treatment System. Process Biochem 38:1031-1037.

11. Wang $\mathrm{H}, \mathrm{Su} J Q$, Zheng XW, Tian $\mathrm{Y}$, Xiong XJ \& Zheng TL (2009). Bacterial decolorization and degradation of the reactive dye Reactive Red 180 by Citrobacter sp. CK3q. Int Biodeter Biodegr 63: 395-399.

12. Kalyani DC, Telke AA, Dhanve RS \& Jadhav JP (2009). Ecofriendly 
biodegradation and detoxification of Reactive Red 2 textile dye by newly isolated Pseudomonas sp. SUK1. J Hazard Mater 163: 735-742.

13. Kalme SD, Parshetti GK, Jadhav SU \& Govindwar SP (2007). Biodegradation of benzidine based dye direct blue- 6 by Pseudomonas desmolyticum NCIM 2112. Bioresour Technol 98: 1405-1410.

14. Telke AA, Joshi SM, Jadhav SU, Tamboli DP\& Govindwar SP (2010). Decolorization and detoxification of Congo red and textile industry effluent by an isolated bacterium Pseudomonas sp. SU-EBT. Biodegr 21: 283-296.

15. Yeh MS \& Chang JS (2004). Bacterial Decolorization Of An Azo Dye With Natural Isolate Of Pseudomonas Luteola And Genetically Modified Escherichia Coli. J Chem Technol 79: 1354-1360.

16. Sarayu K \& Sandhya S (2010). Aerobic Biodegradation Pathway for Remazol Orange by Pseudomonas aeruginosa. Appl Biochem Biotechnol 160: 12411253.

17. Nachiyar CV \& Rajakumar GS (2005). Isolation and screening of azo dye decolorizing bacterial isolates from dyecontaminated textile waste. Enzyme Microb Technol 36: 503-509.

18. Forgacs E, Cserháti T \& Oros G (2004). Removal of synthetic dyes from wastewaters: a review. Environ Int 30: 953-971.

19. Dias A, Sampaio A \& Bezerra R (2007). Environmental applications of fungal and plant systems: decolorization of textile wastewater and related dyestuffs. In: Singh S, Tripathi R (eds) Environ Biorem Technol Springer, Heidelberg, 445-463.

20. Plácido J, Chanagá X, Ortiz-Monsalve S, Yepes M \& Mora A (2016). Degradation and detoxification of synthetic dyes and textile industry effluents by newly isolated Leptosphaerulina sp. from Colombia. Bioresour. Bioprocess 3: 1-14.
21. Shin KS, Ho IK \& Kim CJ (1997). Production and purification of remazol brilliant blue $\mathrm{R}$ decolorizing peroxidase from the culture filtrate of Pleurotus ostreatus. Appl Environ Microbiol 63: 1744-1748.

22. Toh YC, Yen JL, Obbard JP \& Ting YP (2003). Decolorization of azo dye by white rot fungi isolated in Singapore. Enzyme Microb Technol 33: 569-575.

23. Soundharya K, Rashika B, Mounica R \& Masi C (2016). Enzymatic treatment of effluents from textile industries. $J$ Chem Pharm Res 8: 382-389.

24. Ollikka P, Alhonmiiki K, Leppanen VM, Glumoff T, Raijola T \& Suominen I (1993). Decolorization of azo, triphenyl methane, heterocyclic, and polymeric dyes by lignin peroxidase isoenzymes form Phanerochaete chrysosporium. Appl Environ Microbiol 59: 4010-4016.

25. Martorell MM, Pajot HF \& de Figueroa LIC (2012). Dye decolorizing yeasts isolated from Las Yungas rainforest Dye assimilation and removal used as selection criteria. Int Biodeter Biodegr 66: 25-32.

26. Elumalai S \& Saravanan GK (2016). The role of microalgae in textile dye industrial waste Water recycle (phycoremediation). Int J Pharm Bio Sci 7: 662-673.

27. Ramachandran $P$, Sundharam R, Palaniyappan J \& Munusamy AP (2013). Potential Process Implicated In Bioremediation of Textile Effluents: A Review. Adv Appl Sci Res 4: 131-145.

28. Gowri RS, Vijayaraghavan R \& Meenambigai P (2014). Microbial degradation of reactive dyes- A Review. Int J curr microbiol appl sci 3: 421-436.

29. Ji Y, Li XT \& Chen GQ (2008). Interactions between a poly (3hydroxybutyrate-co-3-hydroxyvalerateco-3-hydroxyhexanoate) terpolyester and human keratinocytes. Biomaterials 29: 3807-3814.

30. Ogugbue CJ \& Sawidis T (2011). Bioremediation and Detoxification of 
Synthetic Wastewater Containing Triarylmethane Dyes by Aeromonas hydrophila Isolated from Industrial Effluent. SAGE-Hind Aces Res Biotechnol Int 6: 21-27.

31. Couto SR (2009). Dye removal by immobilised fungi. Biotechnol Adv 27: 227-235.

32. Marimuthu $\mathrm{T}$, Rajender $\mathrm{R} \quad$ \& Manivannan M (2013). A Review on Fungal Degradation of Textile Dye Effluent. Acta Chim Pharm Indica 3:192-200.

33. Christie R (2001). Color Chemistry. The Royal Society of Chemistry, Cambridge, United Kingdom.

34. Welham A (2000). The theory of dyeing (and the secret of life). J Soc Dye Colour 116: $140-143$.

35. Anliker R (1979). Ecotoxicology of dyestuffs-a joint effort by industry. Ecotox Environ Safe 3: 59-74.

36. Carliell CM, Barclay SJ, Naidoo N, Buckley CA, Mulholland DA \& Senior E (1995). Microbial Decolorization of A Reactive Azo Dye Under Anaerobic Conditions. Wat SA 21:61-70.

37. Ali N, Hameed A \& Ahmed S (2010). Role of Brown-Rot Fungi in the Bioremoval of Azo Dyes under Different Conditions .Brazilian J Microbiol 41: 907-915.

38. Wijetunga S, Xiufen L, Wenquan R \& Chen J (2007). Removal Mechanisms of Acid Dyes of Different Chemical Groups Under Anaerobic Mixed Culture. Ruhuna J Sci 2: 96-110.

39. Joshi M, Bansal R \& Purwar R (2004). Colour Removal from Textile Effluents. A Review. Indian J Fibre Text Res 29: 239-259.

40. Abraham TE, Senan RC, Shaffiqu TS, Jegan J, Roy T, Poulose P \& Thomas PP (2003). Bioremediation of Textile Azo Dyes by an Aerobic Bacterial Consortium Using a Rotating Biological Contactor. Biotechnol Prog 19: 13721376.
41. Telke A, Kalyani D, Jadhar J \& Govindwar S (2008). Kinetics and Mechanism of reactive red 141 Degradation by a bacterial isolate Rhizobium radiobacter MTCC8161. Acta Chim Slov 55: 320 -329.

42. Ventura-Camargo BC \& Marin-Morales MA (2013). Azo Dyes: Characterization and Toxicity- A Review. Text Light Indust Sci Technol (TLIST) 2: 85-103.

43. Correia VM, Stephenson T \& Judd SJ (1994). Characterization of textile wastewaters: a review. Environ Technol 15: 917-919.

44. Jadhav JP, Kalyani DC, Telke AA, Phugare SS \& Govindwar SP (2010). Evaluation of the efficacy of a bacterial consortium for the removal of color, reduction of heavy metals, and toxicity from textile dye effluent. Bioresour Technol 101: 165-173.

45. Pearce CI, Lloyd JR \& Guthrie JT (2003). The Removal of Colour from Textile Wastewater Using Whole Bacterial Cells: A Review. Dyes Pigments 58: 179-186.

46. Junnarkar N, Murty DS, Bhatt NS \& Madamwar D (2006). Decolorization of diazo dye remazol brilliant orange 81 by a novel bacterial consortium. World $J$ Microbiol Biotechnol 22: 163-168.

47. Mahmood R, Sharif F, Ali S \& Hayyat MU (2013). Bioremediation of Textile Effluent by Indigenous Bacterial Consortia and Its Effects on Zea Mays L. Cv C1415. J Anim Plant Sci 23:11931199.

48. Zablocka-Godlewska E, Przystas W \& Grabinska-Sota E (2009). Decolourization of triphenylmethane dyes and ecotoxicity of their end products. Environ Prot Eng 35: 161169.

49. Aktar K, Zerin T \& Banik A (2019). Biodegradation of textile dyes by bacteria isolated from textile industry effluents. Stamford J Microbiol 9: 5-8.

50. Shinkafi MS, Mohammed IU \& Audu AA (2015). Degradation and 
decolourization of textile dyes effluents. European J Biotechnol Biosci 3: 06-11.

51. Horitsu H, Takada M, Idaka E, Tomoyeda M \& Ogawa T (1997). Degradation of aminoazo benzene by Bacillus subtilis. European $J$ Appl Microbiol 4: 217 -224.

52. Chen $\mathrm{KC}, \mathrm{Wu} \mathrm{JY}$, Huang CC, Liang YM $\&$ Hwang SCJ (2003). Decolorization of azo dye using PVA-immobilized microorganisms. J biotechnol 101: 241252.

53. Nakanishi $\mathrm{M}$, Yatome $\mathrm{C}$, Ishida $\mathrm{N} \&$ Kitade Y (2001). Putative ACP phosphodiesterase gene (acpD) encodes an azoreductase. $J$ Biol Chem 276: 46394-46399.

54. Coughlin MF, Kinkle BK \& Bishop PL (1999). Degradation of azo dyes containing aminonaphthol by Sphingomonas sp. strain 1CX. J Ind Microbiol Biotechnol 23: 341-346.

55. Hu TL (1992). Algal degradation and decolourization of textile effluents. Water Sci Technol 26:357-366.

56. Won SW \& Yun YS (2008). Biosorptive removal of reactive yellow 2 using waste biomass from lysine fermentation process. Dyes Pigment 76: 502- 507.

57. Singh L \& Singh VP (2015). Textile Dyes Degradation: A Microbial Approach for Biodegradation of Pollutants. Environ Sci Eng 2015:187204.

58. Nigam P, Banat IM, Singh D \& Marchant R (1996). Microbial process for the decolorization of textile effluent containing azo, diazo and reactive dyes. Process Biochem 31: 435-42.

59. Keharia H \& Madamwar D (2003). Bioremediation concepts for treatment of by containing water: A review. Indian J Exp Biol 41: 1068-1074.

60. Ayman YI, Ewida A, El-Sesy ME \& Zeid AA (2019). Complete degradation of azo dye acid red 337 by Bacillus megaterium KY848339.1 isolated from textile wastewater. Water Sci 33: 154-161
61. Singh L (2017). Biodegradation of synthetic dyes: a mycoremediation approach for degradation/decolourization of textile dyes and effluents. J Appl Biotechnol Bioeng 3: 430-435.

62. Khandare RV \& Govindwa SP (2016). Microbial Degradation Mechanism of Textile Dye and Its Metabolic Pathway for Environmental Safety. Taylor \& Francis Group, LL. pp 412.

63. Dilek FB, Taplamacioglu HM \& Tarlan E (1999). Color and AOX removal from pulping effluents by algae. Appl Microbiol Biotechnol 52: 585-591.

64. Ozdemir G, Pazarbasi B, Kocyigit A, Omeroglu EE, Yasa I \& Karaboz J (2008). Decolorization of Acid Black 210 by Vibrio harveyi TEMS1, a newly isolated bioluminescent bacterium from Izmir Bay, Turkey. World J Microbiol Biotechnol 24: 1375-1381.

65. Mallick N (2002).Biotechnological potential of immobilized algae for wastewater NP and Metal removal A review. Biometals 15:377-390.

66. Korner S \& Vermaat JE (1998). The relative importance of Lemna gibba L., bacteria and algae for the nitrogen and phosphorus removal in duckweedcovered domestic wastewater. Water Res 32:3651-3661.

67. Ozturk A \& Abdullah MI (2006). Toxicological effect of indole and its azo dye derivatives on some microorganisms under aerobic conditions. Sci Total Environ 358: 137-142.

68. Khalid A, Arshad M \& Crowley DE (2008). Accelerated decolorization of structurally different azo dyes by newly isolated bacterial strains. Appl Microbiol Biotechnol 78: 361-369.

69. Dubey SK, Dubey J, Viswas AJ \& Tiwari $P$ (2011). Studies on Cyanobacterial biodiversity in paper mill and pharmaceutical industrial effluents. $\mathrm{Br}$ Biotechnol J 1: 61-67.

70. Daneshvar N, Ayazloo M, Khataee AR \& Pourhassan M (2005). Biodegradation 
of the Textile Dye Malachite Green by Microalgae Cosmarium sp. Water and waste Treatment Research Laboratory, Department of Applied Chemistry, university of Tabriz, Tabriz, Iran

71. Omar HH (2008). Algal Decolorization and Degradation of Monoazo and Diazo Dyes. Pak J Biol Sci 1: 1310-1316.

72. Gajare SM \& Menghani S (2012). Biosorption of malachite green by naturally grown algal from Girna river, Jalgaon district, Maharashtra. J Algal Biomass Utill 3: 60-65.

73. Elisangel AFZ, Andrea DG, Fabio R, Cristiano D \& Regina C (2009). Biodegradation of textile azo dyes by a facultative Staphylococcus arlettae strain VN-11 using a sequential microaerophilic/ aerobic process. Int Biodeter Biodeg 63: 280-288.

74. Meehan C, Banat IM, McMullan G, Nigam P, Symth F \& Maarchant R (2000). Decolorization of Removal Black B using a thermotolerant Yeast, Kluyveromyces marxianus IMBS. Environ Int 26: 75 - 79.

75. Cheriaa j, Bettaieb F, Denden I \& Bakhrouf A (2009). Characterization of new algae isolated from textile wastewater plant. J Food Agric Environ 7: 700-704.

76. Brahmbatt NH, Jasrai RT (2016). Role of Algae in bioremediation of textile effluents. Int J Eng Res Gen Sci 4: 443453.

77. Dellamatricea PM, Silva-Stenicob ME, Beraldo de Moraesc LA, Fioreb MF, Monteiro RTR (2017). Degradation of textile dyes by cyanobacteria. Brazilian $J$ Microbiol 48: 25-31.

78. Henciya S, Shankar MA \& Malliga $\mathrm{P}$ (2013). Decolorization of Textile dye effluent by Marine cyanobacterium Lyngbya sp. BDU 9001 with coir pith. Int J environ sci 3: 644-651.

79. El-Sheekh MM, Gharieb MM \& AbouEl-Souod GW (2009). Biodegradation of dyes by some green algae and cyanobacteria. Int Biodeter Biodegr 63: 699-704.

80. Zhang ZB, Liu CY, Wu ZZ, Xing L \& Li PF (2006). Detection of nitric oxide in culture media and studies on nitric oxide formation by marine microalgae. Med Sci Monit 12: 75-85.

81. Varsha YM, Naga Deepthi CH \& Chenna S (2011). An Emphasis on Xenobiotic Degradation in Environmental Cleanup. J Bioremediat Biodegrad 11: 230-237.

82. Gowri RS, Vijayaraghavan R \& Meenambigai P (2014). Microbial degradation of reactive dyes. A Review. Int J curr microbiol appl sci 3:421-436.

83. Ozer A, Akkaya G \& Turabik M (2006). The Removal Ofacid Red 274 from Wastewater: Combined Biosorption and Biocoagulation with Spirogyra Rhizopus. Dyes Pigment 71: 83-89.

84. Hammel KE (1996). Extra cellular free radical biochemistry of ligninolytic fungi. New J Chem 20: 195-198.

85. Dos Santos AB, Cervantes FJ \& Van Lier JB (2007). Review Paper on Current Technologies for Decolorization of Textile Wastewaters: Perspectives For Anaerobic Biotechnology. Bioresour Technol 98: 2369-2385.

86. Ali N, Hameed A \& Ahmed S (2010). Role of Brown-Rot Fungi in the Bio removal Of Azo Dyes under Different Conditions. Braz J Microbiol 41: 907915.

87. Asgher $M$, Bhatti HN, Ashraf $M$ \& Legge RL (2008). Recent developments in biodegradation of industrial pollutants by white rot fungi and their enzyme system. Biodegradation 19:771-783.

88. Hatakka A (1994). Lignin modifying enzymes from selected white rot fungi: production and role in lignin degradation. FEMS Microbiol Rev 13: 125-135.

89. Shanmugapriya A \& Somasundaram S (2016). Enhancement of Dye Degradation Activity by Microorganisms-A Review. Int J Pharm Bio Sci 7: 122-133. 
90. Toh YC, Yen JJL, Obbard JP, Ting YP (2003). Decolourisation of azo dyes by White-rot fungi (WRF) isolated in Singapore. Enzyme Microb Tech 33: 569-575.

91. Heinfling A, Bergbauer M \& Szewzyk U (1997). Biodegradation of azo and phthalocyanin dyes by Trametes versicolor and Bjerkandera adusta. Appl Microbiol Biotechnol 48: 261-266.

92. Moreira MT, Mielgo I, Fejio G \& Lema JM (1996).Evaluation of different fugal strains in the decolourization of synthetic dyes. Biotechnol Lett 18: 117-120.

93. Arora DS, Chander $M$ \& Gill PK (2002).Involvement of lignin peroxidase, managanese peroxidas and laccase in degradation and selective lihninolysis of wheat straw. Int Biodeter Biodegrad 50: 115-120.

94. Knapp JS, Zhang F, Tapley KN (1997). Decolourization of orange II by a wood rotting fungus. $J$ chem Technol Biotechnol 69: 289-296.

95. Novotny C, Svobodova K, Kasinath A \& Erbanova P (2004). Biodegradation of synthetic dyes by Irpex lacteus under various growth conditions. Int Biodeter Biodegrad 54: 215-223.

96. Ozsoy HD, Unyayar A \& Mazmanci MA (2005).Decolourization of reactive textile dyes Drimarene blue X3LR and ramzol brilliant blue $\mathrm{R}$ by Funalia trogii ATCC 200800. Biodegradation 16: 195 204.

97. Tychanowicz GK, Zilly A, Giatti C, de Souza M \& Peralta R (2004). Decolorization of industrial dyes by solid-state cultures of Pleurotus pulmonarius. Process Biochem 39: 855859

98. Shrivastava R, Christian V \& Vyas BRM (2005). Enzymatic decolorization of sulfonphthalein dyes. Enzyme Microb Technol 36: 333-337.

99. Senthilkumar S, Perumalsamy M \& Prabhu HJ (2014). Decolourization potential of white-rot fungus
Phanerochaete chrysosporium on synthetic dye bath effluent containing Amido black 10B. J Saudi Chem Society 18: 845-853.

100. Kim SU, Cheong YH, Seo DC, Hur JS, Heo JS \& Cho JS (2007). Characterisation of heavy metal tolerance and biosorption capacity of bacterium strain CPB4 (Bacillus spp.). Water Sci Technol 55: 105-111.

101. Reddy CA (1995). The Potential for White Rot Fungi in the Treatment of Pollutants. Curr Opin Biotechnol 6: 320328.

102. Michel Jr FC, Dass SB, Grulke EA \& Reddy CA (1991). Role of Manganese Peroxidases and Lignin Peroxidases of Phanerochaete Chrysosporium in the Decolorization of Kraft Bleach Plant Effluent. Appl Environ Microbiol 57: 2368-2375.

103. Sharma S, Singh A, Mathur N \& Verma A (2013). Development of Fungal Consortium for Biodecolorization of Textile Waste Effluents: A Review. Int J Chem Sci 11: 891-910.

104. Townsley CC \& Ross IS (1986). Copper uptake in Aspergillus niger during batch growth and in non-growing mycelial suspensions. Exp Mycol 10: 281-288.

105. Yan G \& Viraraghavan T (2003). Heavymetal removal from aqueous solution by fungus Mucor rouxii. Wat Res 37: 44864496.

106. Bai SR \& Abraham TE (2001). Biosorption of $\mathrm{Cr}$ (VI) from aqueous solution by Rhizopus nigricans. Bioresour Technol 79: 73-81.

107. Ahluwalia SS \& Goyal D (2007). Microbial and plant derived biomass for removal of heavy metals from wastewater. Bioresour Technol 98: 2243-2257.

108. Niu H, Xu XS, Wang JH \& Volesky B (1993). Removal of Lead from aqueous solution by penicillum biomass. Biotechnol Bioeng 44:785-787.

109. Glenn JK \& Gold MH (1983). Decolorization of several polymeric dyes 
by the lignin-degrading basidiomycete Phanerochaete chrysosporium. Appl Environ Microbiol 45: 1741-1747.

110. Swamy J \& Ramsay JA (1999). The evaluation of white rot fungi in the decoloration of textile dyes. Enzyme Microb Technol 24: 130-137.

111. Underkofler LA, Barton RR \& Rennert SS (1957). Production of Microbial Enzymes and Their Applications Microbiological Process Report.

112. Conesa A, Punt PJ \& Hondel VD (2002). Fungal Peroxidases: Molecular aspects And Applications. J Biotechnol 93:143158.

113. Guill'en F, Mart'inez AT \& Mart'inez MJ (1992). Substrate specificity and properties of the aryl-alcohol oxidase from the ligninolytic fungus Pleurotuseryngii. Eur J Biochem 209: 603-611.

114. Wesenberg D, Kyriakides I, Spiros \& Agathos N (2003). White-rot fungi and their enzymes for the treatment of industrial dye effluents. Biotechnol Adv 22: 161-187.

115. Pointing \& Vrijmoed (2000). Algal decolourization of azo dyes. World $J$ Microbiol Biotechnol 16: 317-318.

116. Limura $Y$, Hartikainen $P$ \& Tatsumi $K$ (1996). Microbial degradation of textile effluents. Appl Microbiol Biotechnol 45: 434-439.

117. Novotny C, Vyas BRM, Erbanova P, Kubatova A \& Sasek V (1997). Removal of PCBs by various white rot fungi in liquid cultures. Folia Microbiol 42: 136140.

118. Glenn JK, Akileswaran L \& Gold MH (1986). Mn (II) oxidation is the principal function of the extracellular Mnperoxidase from Phanerochaete chrysosporium. Arch Biochem Biophys 251: 688-696.

119. Joshni T, Chacko \& Subramaniam K (2011). Enzymatic Degradation of Azo Dyes - A Review. Int J Environ Sci 1: 1250-1259.
120. Ezeronye OU \& Okerentugba PO (1999). Performance and efficiency of a yeast biofilter for the treatment of a Nigerian fertilizer plant effluent. World $J$ Microbiol Biotechnol 15: 515-516.

121. Saratale RG, Saratale GD, Chang JS \& Govindwar SP (2011). Bacterial decolorization and degradation of azo dyes: A review. J Tailand Inst Chem Eng 42: $138-157$.

122. Awomeso JA, Taiwo AM, Gbadebo A \& Adenowo JA (2010). Studies on the pollution of waterbody by textile industry effluents in Lagos, Nigeria. $J$ Appl Sci Environ Sanit Sby 5: 353-359.

123. Behel S \& Kumar S (2013). In situ Degradation of textile dyes using biological methods. Int J Sci Emerg Technol Latest Trends 7: 26-31.

124. Mojos DK, Andronikov D, Janevski A, Kuzelov A \& Gaber S (2016). The application of enzymes for the removal of dyes from textile effluents. $A d v$ technol 51: 81-86.

125. Gianfreda L, Xu F \& Bollag JM (1999). Laccases: A Useful Group of Oxidoreductive Enzymes. Biorem J 3: 126.

126. Heinfling A, Martinez MJ, Martinez AT, Bergbauer M \& Szewczyk U (1998). Transformation of industrial dyes by manganese peroxidases from Bjerkandera adusta and Pleurotus eryngii in a manganese-independent reaction. Appl Environ MircobioI 64: 2788-93.

127. Jin XC, Liu GQ, Xu Z \& Tao WY (2007). Decolorization of a dye industry effluent by Aspergillus fumigatus XC6. Appl Microbiol Biotechnol 74: 239-243.

128. Hasan F, Shah AA \& Hameed A (2006). Industrial applications of microbial lipases. Enzyme Microb Technol 39: 235-251.

129. Zille A, Ramalho P, Tzanov A, Millward R, Aires V, Cardoso MH, Ramalho MT, Gübitz GM \& Cavaco-Paulo A (2004). Enhanced decolorization of Solar brilliant red 80 textile dye by an 
indigenous white rot fungus Schizophyllum commune IBL-06. Biotechnol Progress 20: 1588-1592.

130. Kalyuzhnyi S, Yemashova N \& Federovich V (2006). Bacterial degradation of azo dyes. Water Sci Technol 54: 73-79.

131. Franciscon E, Zille A \& Durran LR (2009). Decolorization and Biodegradation of Reactive Sulfonated Azo Dyes By A Newly Isolated Brevibacterium Sp. Strain VN-15. Int Biodeter Biodegrad 63: 280-288.

132. Peralta-Zamora P, Pereira C, Tiburtius E, Moraes S, Rosa M, Minussi R \& Duran $\mathrm{N}$ (2003).Decolorization of reactive dyes by immobilized laccase. Appl Catal B 42: 131144.

133. Mane UV, Gurav PN, Deshmukh AM \& Govindwar SP (2008). Degradation of textile dye reactive navy blue $\mathrm{RX}$ (Reactive blue 59) by an isolated Actinomycetes Streptomycetes Krainskii SUK 5. Malays J Microbiol 4: 15.

134. Machado KMG \& Matheus DR (2006). Biodegradation of Remazol brilliant blue $\mathrm{R}$ by Ligninolytic enzymatic Complex produced by Pleurotus Ostreatus. Brilliant J Microbiol 37: 468- 473.

135. Imran M , David E, Crowley, Khalid A, Hussain S, Mumtaz MW \& Arshad M (2014). Microbial biotechnology for decolorization of textile Wastewaters. Rev Environ Sci Biotechnol 9: 32-37.

136. Sarayu K \& Sandhya S (2010). Aerobic biodegradation pathway for Remazol orange by Pseudomonas aeruginosa. Appl Biochem Biotechnol 160: 12411253.

137. Chang JS \& Kuo TS (2000). Kinetics of bacterial decolorization of azo dye with Escherichia coli NO3. Bioresour Technol 75: 107-111.

138. $\mathrm{Hu}$ TL (1994). Decolourization of reactive azo dyes by transformation with Pseudomonas luteola. Bioresour Technol 49:47 - 51.

139. Wong PK \&Yuen PY (1998). Decolourization and biodegradation of
$\mathrm{N}, \mathrm{N}^{\prime}$-dimethyl- $p$-phenylenediamine by Klebsiella pneumoniae RS-13 and Acetobacter liquefaciens S-I. J Appl Microbiol 85: 79-87.

140. Scheline RR \& Longberg B (1965). The absorption, metabolism, and excretion of the sulphonated azo dye, acid yellow, by rats. Acta Pharmacol Toxicol 23: 1-14.

141. Scheline RR, Nygaard RT \& Longberg B (1970). Enzymatic reduction of azo dye, acid yellow, by extracts of Streptococcus faecalis isolated from rat intestine. Food Cosmet Toxicol 8: 55-58.

142. Wuhrmann K, Mechsner K \& Kappeler $\mathrm{T}$ (1980). Investigation on ratedetermining factor in the microbial reduction of azo dyes. European J Appl Microbiol Biotechnol 9: 325-338.

143. Paszczynski A, Pasti MB, Goszczynski S, Crawford DL \& Crawford RL (1991). New approach to improve degradation of recalcitrant azo dyes by Streptomyces sp. and Phanerochaete chrysosporium. Enzyme Microbiol Technol 13: 378-383.

144. Volesk B \& May-Phillips HA (1995). Biosorption of heavy metals by Saccharomyces cerevisiae. $J$ Appl Microbiol Biotechnol 42: 797- 806.

145. Jadhav JP \& Govindwar SP (2007). Yeast decolorization of azo dyes. Bioresour Technol 23: 316-323.

146. Ramalho PA, Cardoso MH, CavacoPaulo A \& Ramalho MT (2004) Characterization of azo reduction activity in a novel ascomycete yeast strain. Appl Environ Microbiol 70: 22792288.

147. Donmez G \& Asku Z (2002). Removal of chromium (VI) from saline wastewater by Dunaliella species. Process Biochem 38: 751-762.

148. Charumathi D \& Das N (2010). Bioaccumulation of synthetic dyes by Candida tropicalis growing in sugarcane bagasse extract medium. Adv Biol Res 4: 233-240.

149. Jafari N, Soudi MR \& KasraKermanshahi R (2014).Biodegradation 
perspectives of azo dyes by yeasts. Microbiol 83:484-497.

150. Yu Z \& Wen X (2005). Screening and identification of yeasts for decoloring synthetic dyes in industrial wastewater. Int Biodeter Biodegr 56: 109-114.

151. Abioye OP, Mustapha OT \& Aransiola SA (2014). Biological Treatment of Textile Effluent Using Candida zeylanoides and Saccharomyces cerevisiae Isolated from Soil. Adv Biol 2014: 1-4.

152. Duran N, Rosa MA, D'Annibale A \& Gianfreda L (2002). Applications of Laccases and Tyrosinases (Phenoloxidases) Immobilized on Different Supports: A Review. Enzyme Microbiol Technol 31: 907-931.

153. Ahalya N, Ramachandra TV \& Kanamadi RD (2003). Biosorption of Heavy Metals. Res J Chem Environ 7: 71-78.

154. Barr DP \& Aust SD (1994). Mechanism of White Rot Fungi to Degrade Pollutants. Environ Sci Technol 28: 78A87A.

155. Sumathi S \& Phatak V (1999). Fungal treatment of bagasse based pulp and paper mill wastes. Environ Technol 19: 93-98.

156. Modak JM \& Natarajan KA (1995). Biosorption of Metals Using Nonliving Biomass-A Review. Minerals Metall Process 12:189-196.

157. Kratochivl D, Pimental P \& Volesky B (1998). Trivalent and Hexavalent Chromium by Seaweed Biosorbent. Environ Sci Technol 32:2693-2698.

158. Alluri HK, Ronda SR, Settalluri VS, Bondili JS, Suryanarayana V \& Venkateshwar P (2007). Biosorption: An eco-friendly alternative for heavy metal Removal. African J Biotechnol 6: 29242931.

159. Malik A (2004). Metal bioremediation through growing cells. Environ Int 30: 261-278.

160. Kadukova J \& Vircikova E. (2005). Comparison of differences between copper bioaccumulation and biosorption. Environ Int 31: 227-232.

161. Gadd GM (1988). Accumulation of metals by microorganisms and algae. In: Rehm, H.J. (Ed.), Biotechnol Microbial Process 6b: 401-433

162. Pardo R, Herguedas M, Barrado E \& Vega M (2003). Biosorption of cadmium, copper, lead and zinc by inactive biomass of Pseudomonas Putida. Anal Bioanal Chem 376: 26-32.

163. Goddard PA \& Bull AT (1989). Accumulation of silver by growing and non-growing populations of Citrobacter intermedius B6. Appl Microbiol Biotech 31: 314-319.

164. Bashar H, Margaritis A, Berutti F \& Maurice B (2003). Kinetics and Equilibrium of Cadmium Biosorption by Yeast Cells $S$. cerevisiae and $K$. fragilis, Int J Chem Reactor Eng 1: 1-16.

165. Veglio F \& Toro L (1997). Polyhydrozoethylmethacrylate (poly HEMA) Tmethylolpropanetrimethacrylate (TMPTM) as a support for metal biosorption by Arthrobacter sp. Hydrometal 44: 317-320.

166. Galun M, Galun E, Siegel BZ, Keller P, Lehr H \& Siegel SM (1987). Removal of metal ions from aqueous solution by penicillum biomass. Kinetics and uptake parameters. Water Air Soil Pollut 33: 359-371. 